\title{
Calcium homeostasis, signalling and protein phosphorylation during calcium-induced conidiation in Penicillium notatum
}

\author{
D. PitT* and J. C. Barnes \\ Department of Biological Sciences, University of Exeter, Exeter EX4 4QG, UK
}

(Received 29 March 1993; revised 9 July 1993; accepted 21 September 1993)

\begin{abstract}
Cytosolic free calcium concentration $\left[\mathrm{Ca}^{2+} \mathrm{I}_{\mathrm{c}}\right.$ of protoplasts from Penicillium notatum was measured using the permeant acetoxy ester (quin-2-AM) of the calcium-chelating fluorescent dye quin-2. Low uptake of the ester occurred at $\mathrm{pH} \mathrm{5.8-7.0}$ and its subsequent hydrolysis was low. Uptake was promoted by an external pH of 5.0 and significant hydrolysis to quin-2 achieved by adjustment of the internal $\mathrm{pH}$ to 7.2 , which was near the optimum of the carboxylic esterases responsible for the hydrolysis. Uptake of $\mathrm{Ca}^{2+}$ was biphasic with the average cell calcium concentration of protoplasts increasing from an initial value of $2 \mu \mathrm{mol}$ to $50 \mu \mathrm{mol}(\mathrm{kg} \text { cell water) })^{-1}$, during attainment of the steady state after $30 \mathrm{~min}$, at which time $\left[\mathrm{Ca}^{2+}\right]_{\mathrm{c}}$ was unchanged at $20 \mathrm{nM}$ but increased to $182 \mathrm{nM}$ at 2-6 h exposure to $2.5 \mathrm{mM}-\mathrm{Ca}^{2+}$. Broadly similar changes in $\left[\mathrm{Ca}^{2+}\right]_{\mathrm{c}}$ were found in protoplasts derived from mycelium samples exposed to $\mathrm{Ca}^{2+}$ over the same period of time. The location of $\mathrm{Ca}^{2+}$ was determined in subfractionated organelles and characterized using enzyme markers and electron microscopy. In $32 \mathrm{~h}$ mycelium preloaded with $\mathrm{Ca}^{2+}$ for $6 \mathrm{~h}, \mathrm{Ca}^{2+}$ was located principally in the mitochondria with lower concentrations associated with the endoplasmic reticulum, Golgi, vacuoles and plasma membrane components. Calcium was not released by inositol 1,4,5-trisphosphate or the calcium ionophore A23187 from any subcellular fractions obtained from mycelium on Percoll gradients, nor from preparations of vacuoles or plasmalemma vesicles, except in the case of mitochondria where rapid release of the ion was achieved by the addition of 2-5 $\mu \mathrm{M}-\mathrm{A23187}$. The anti-calmodulin agent calmidazolium (R24571) greatly reduced sporulation when addition preceded that of $\mathrm{Ca}^{2+}$. Calcium-induced cultures showed massive novel protein phosphorylation $2 \mathrm{~h}$ after addition of the ion which was virtually eliminated by R24571, whilst $1 \mathrm{~h}$ and 4-6 h protein phosphorylations, which were also present to some degree in vegetative controls, were substantially reduced. Two-dimensional SDS-PAGE analysis of phosphoproteins confirmed that $\mathrm{Ca}^{2+}$-induced mycelium had enhanced capacity for calmodulin-mediated phosphorylation relative to corresponding vegetative cells and that complex differential changes in such phosphorylations occurred during $\mathrm{Ca}^{2+}$-induction of the sporulation process.
\end{abstract}

\section{Introduction}

Whereas the concept of second messengers, linked through inositide lipid metabolism, has been invoked to explain many cellular responses to external stimuli in animal cells (Berridge, 1987; Berridge \& Irvine, 1984), the position in fungi is unclear (Pitt \& Kaile, 1990). However, the occurrence of polyphosphoinositides in

*Author for correspondence. Tel. +44392 264609; fax +44392 263700 .

Abbreviations: $\left[\mathrm{Ca}^{2+}\right]_{\mathrm{c}}$, cytosolic free $\mathrm{Ca}^{2+} ; \mathrm{ER}$, endoplasmic reticulum; Ins 1,4,5 $\mathrm{P}_{3}$, inositol 1,4,5-trisphosphate; quin-2, 2-[[2[bis(carboxymethyl)amino]-5-methyl-phenoxy]-methyl]-6-methoxy-8[bis(carboxymethyl)amino]quinoline. fungi is established (Weete, 1974; Bowman et al., 1987) and phosphatidylinositol 4,5-bisphosphate has been reported in Fusarium (Robson et al., 1991). These observations, coupled with the occurrence of phospholipases of suitable specificities for inositol lipid turnover (Weete, 1974), suggest that fungi may possess the framework for signal transduction proposed for higher organisms.

The discovery of a calcium-binding protein in Blastocladiella (Gomes et al., 1979) and of calmodulin in Penicillium notatum (Muthukumar et al., 1987) along with the detection of calmodulin and identification of a calcium- and phospholipid-dependent protein kinase C in Neurospora crassa (Favre \& Turian, 1987) implies that $\mathrm{Ca}^{2+}$ may serve regulatory functions during development of filamentous fungi. Involvement of calmodulin in 
regulating calcium-stimulated reproduction is now indicated in Phytophthora (Elliott, 1986) and P. notatum (Pitt $\&$ Kaile, 1990). A rôle for calmodulin-mediated protein kinase $\mathrm{C}$ and calcium in yeast-mycelium transition of Ophiostoma ulmi has been proposed (Brunton \& Gadd, 1991; Gadd \& Brunton, 1992).

Several penicillia, including $P$. notatum (Hadley \& Harrold, 1958 a, b; Pitt \& Poole, 1981) and P. cyclopium (Ugalde \& Pitt, 1983) may be induced to conidiate by $\mathrm{Ca}^{2+}(10 \mathrm{~mm})$ in submerged aerated cultures, which are not nutrient-depleted. Addition of $\mathrm{Ca}^{2+}$ reduces biomass production for a $12 \mathrm{~h}$ period, during which phialide differentiation is completed, followed by resumption of growth comprising mainly spore production. The check to biomass production, which is diauxic in nature, has been correlated with metabolic changes in the routes of carbohydrate catabolism towards those based on gluconate utilization (Pitt \& Mosley, 1985a, $b, 1986$ ). In association with substantial biphasic uptake of $\mathrm{Ca}^{2+}$ (Ugalde \& Pitt, 1986) and its accumulation at subcellular sites, mitochondrial and respiratory metabolism became grossly modified (Pitt \& Mosley, 1986).

Although several $\mathrm{Ca}^{2+}$-sensitive metabolic targets have been identified during calcium-induced conidiation in $P$. notatum, the temporal relationships between regulation of these and $\mathrm{Ca}^{2+}$ homeostasis in the system are unclear. The present paper examines the rôle of $\mathrm{Ca}^{2+}$, as a primary signal, in relation to cytosolic free calcium concentration and the involvement of calmodulin in protein phosphorylation during $\mathrm{Ca}^{2+}$-induced sporulation in P. notatum.

\section{Methods}

Organism, media and growth conditions. Batch cultures of Penicillium notatum Westling, IMI 15378, were grown in 2 litre fermenters at $25^{\circ} \mathrm{C}$. Sporulation in $32 \mathrm{~h}$ vegetative cultures was induced by the addition of calcium chloride to $10 \mathrm{~mm}$ concentration (Pitt \& Poole, 1981).

Protoplast production. This was done on mycelium using Novozyme 234 (Pitt et al., 1988; Roncal et al., 1991).

Cell fractionation and organelle production. Protoplasts were prepared and resuspended in $15 \mathrm{ml} 0 \cdot 1 \mathrm{M}-\mathrm{MES} / \mathrm{NaOH}$ buffer, pH $5 \cdot 8$, containing $0.25 \mathrm{M}$-sucrose, $1 \mathrm{mM}$-EDTA, $0.01 \%(\mathrm{v} / \mathrm{v})$ mercaptoethanol and $0.01 \%(\mathrm{w} / \mathrm{v})$ cysteine hydrochloride. Resuspended protoplasts $(15 \mathrm{ml})$ were homogenized with $15 \mathrm{ml}$ of glass beads $(0.3-0.5 \mathrm{~mm}$ diam.) in a BeadBeater (Biospec) for $10 \mathrm{~s}(\times 3)$ at $0{ }^{\circ} \mathrm{C}$, centrifuged at $350 \mathrm{~g}$ for $5 \mathrm{~min}$ and resuspended in $12 \mathrm{ml}$ of homogenization medium. The homogenate was layered onto a gradient consisting of $50 \%(\mathrm{w} / \mathrm{v})$ Percoll in homogenization medium, from which EDTA was excluded, and fractionated according to Ugalde \& Pitt (1984). Fractions $(28 \times 1.52 \mathrm{ml})$ were collected and densities determined by refractometry.

Plasma membrane vesicles of controlled orientation were prepared from protoplasts by the methods of Ugalde (1991) or Ugalde et al. (1992) using enzyme-assisted physical homogenization, differential centrifugation and partitioning in an aqueous polymer two-phase system.
Vacuoles prepared from $40 \mathrm{~h}$ mycelium of $P$. notatum, by the method of Cramer et al. (1983), were numerous but of small size $(<100 \mathrm{~nm})$. A larger range of sizes $(0.1-1 \cdot 0 \mu \mathrm{m})$ was obtained from both vegetative and calcium-induced mycelium, using the method of Cornelius et al. (1989) and showed high marker $\mathrm{H}^{+}$-ATPase activity.

Calcium determinations. The ${ }^{45} \mathrm{Ca}^{2+}$ content of protoplasts or organelles derived from mycelium grown in the presence of 2.5-10 mMcalcium supplemented with $1 \cdot 25-5 \mu \mathrm{M}{ }^{45} \mathrm{Ca}^{2+}[0 \cdot 37-1 \cdot 5 \mathrm{GBq}(\mathrm{mg}$ calcium $)^{-1}$; Amersham] was measured by liquid scintillation counting according to Ugalde \& Pitt (1984) or Pitt et al. (1988), as appropriate. Non-radioactive calcium in various samples, and the basal calcium content of media and reagents, was determined at $422.7 \mathrm{~nm}$ by atomic absorption spectrophotometry (Pye Unicam SP9).

Calcium accumulation and release. The kinetics of calcium uptake, the dissociation constant $\left(K_{\mathrm{D}}\right)$ and the binding capacity $\left(Y_{t}\right)$ for mycelium and protoplasts were studied by the procedures of Ugalde \& Pitt (1986) and Pitt et al. (1988).

Efflux of ${ }^{45} \mathrm{Ca}^{2+}$ from preloaded mycelium and protoplasts was examined by sampling washed preparations followed by rapid (10 s) centrifugation at $18000 \mathrm{~g}$ in a microcentrifuge and determination of radioactivity in the supernatant fluid fractions.

Rapid release of calcium from subcellular fractions and membrane preparations was monitored using quin-2 whereby the appropriate suspending medium, to which ATP $(0.4 \mathrm{mM})$ was added and from which EDTA was excluded, was equilibrated with quin-2 $(50-100 \mu \mathrm{M})$ and suitably diluted (e.g. 1:10) fractions in a total volume of $2 \mathrm{ml}$. Adjustment of vesicle and quin-2 concentrations between samples overcame the varying basal levels of $\mathrm{Ca}^{2+}$ therein and ensured the quin2 signal remained unsaturated. The effects were examined on calcium release of additions of aqueous inositol 1,4,5-trisphosphate (Ins 1,4,5, $\mathrm{P}_{3}$ ) at final concentrations of $2 \cdot 5-40 \mu \mathrm{M}$, and freshly prepared calcium ionophore A23187 $(0.5-10 \mu \mathrm{M})$ in freshly distilled dry dimethylsulphoxide (DMSO). Fluorescence was continuously recorded in stirred samples at $25^{\circ} \mathrm{C}$ using a Perkin-Elmer LS-5B luminescence spectrometer with excitation and emission wavelengths of $339 \mathrm{~nm}$ and $492 \mathrm{~nm}$, respectively, and slit widths of $2.5 \mathrm{~nm}$. Known amounts of $\mathrm{Ca}^{2+}$ were added to aliquots of the various samples in order to calibrate the ordinate scale, with $\mathrm{Ca}^{2+}$ released expressed as nmol ( $\mathrm{mg}^{2}$ protein $)^{-1}$.

Calcium-sensitive micro-electrodes with membranes containing the neutral ionophore ETH 1001 were constructed according to Prentki et al. (1983).

Cytosolic free calcium concentration of protoplasts. Estimation of this was done with the acetoxymethyl ester of quin-2 (quin-2-AM) following adjustments of the average internal $\mathrm{pH}$ of protoplasts to 5.0 for loading the ester, and subsequently to $\mathrm{pH} 7.2$ for optimum internal hydrolysis of it. Protoplasts $\left(4 \times 10^{8} \mathrm{ml}^{-1}\right)$ in $50 \mathrm{~mm}$-potassium hydrogen phthalate buffer adjusted to $\mathrm{pH} 5.0$ with tetramethylammonium hydroxide, containing $1.2 \mathrm{M}$-sorbitol and $50 \mathrm{~mm}$-glucose, were loaded, with aeration, for $90 \mathrm{~min}$ in quin-2-AM $(50 \mu \mathrm{M})$. The internal $\mathrm{pH}$ of cells was adjusted ( $\mathrm{pH} \mathrm{7.2)}$ by transferring to $0.1 \mathrm{M}-\mathrm{MOPS} / \mathrm{NaOH}$ buffer containing $1.2 \mathrm{M}$-sorbitol and $50 \mathrm{~mm}$-glucose, $\mathrm{pH} 7.5$, which gave an internal concentration of approx. $0.5 \mathrm{~mm}$-quin-2. Fluorescence was continuously recorded, as above, and cytosolic free calcium concentration was calculated according to the equation of Tsien et al. (1982), as described by Pitt \& Kaile (1990). Since the apparent dissociation constant $\left(K_{\mathrm{D}}\right)$ is influenced by free magnesium concentration, temperature and $\mathrm{pH}$, the effective $K_{\mathrm{D}}$ for the present conditions was calculated as $238 \mathrm{~nm}$ following the use of calcium buffers (Tsien et al, 1982).

pH optima of quin-2 acetoxymethyl esterase. Protoplasts were prepared and homogenized as for organelle fractionation (see above) 
and freed from organelles and particle-bound carboxylic esterases by centrifugation at $180000 \mathrm{~g}$ for $60 \mathrm{~min}$ at $0{ }^{\circ} \mathrm{C}$, and aliquots of the supernatant fluid fraction were subjected to gel electrophoresis and staining for carboxylic esterases using $\alpha$-naphthyl acetate as substrate (Pitt, 1970). Replicate unstained gels were sliced horizontally into $2 \mathrm{~mm}$ sections and eluted separately in $1 \mathrm{ml}$ aliquots of buffers $(\mathrm{pH} \mathrm{3-10)}$. Eluates were incubated with quin-2-AM $(10 \mu \mathrm{M})$ for $1 \mathrm{~h}$ at $25^{\circ} \mathrm{C}$ and assayed for the presence of the free acid (quin-2) in the presence of saturating $\mathrm{Ca}^{2+}$ concentrations.

Determination and adjustment of $\mathrm{pH}$ of protoplasts. Average cell $\mathrm{pH}$ was determined with fluorescein diacetate by the method of Roos \& Lückner (1984). Emissions were read at $520 \mathrm{~nm}$ after excitations at $435 \mathrm{~nm}$ and $490 \mathrm{~nm}$. A standard curve was constructed relating internal $\mathrm{pH}$ and external $\mathrm{pH}$ (Slavik, 1982) and used to adjust internal $\mathrm{pH}$.

Water content of protoplasts. This was determined as $63 \%(\mathrm{w} / \mathrm{v})$ using the tritiated water method of Freedman \& Raff (1975).

Enzyme assays. Fractions were assayed for various marker enzymes. Cytochrome oxidase was determined by the method of Cooperstein \& Lazarow (1951). ATPase activity was measured by the release of inorganic phosphate from ATP according to Bowman et al. (1981) as modified by Ugalde (1991). Vanadate $(100 \mu \mathrm{M})$, azide $(5 \mathrm{mM})$, nitrate ions $(50 \mathrm{~mm})$ or molybdate $(0.1 \mathrm{~mm})$ were included to distinguish various ATPases, as appropriate. Cytochrome $c$ oxidoreductase (NADPH) activity was used to locate endoplasmic reticulum (ER) membranes (Hodges \& Leonard, 1974). Latent IDPase, as a marker of Golgi vesicles, was determined as liberated inorganic phosphate by the method of Hodges \& Leonard (1974) with the inclusion of ammonium molybdate to inhibit non-specific phosphatases. Vacuolar ATPase was determined by the method of Bowman (1983). In all ATPase assays inorganic phosphate was assayed according to Fiske \& SubbaRow (1925).

Mitochondrial respiration. Respiration was measured using a Clarktype electrode and respiratory criteria confirmed by analyses of oxygen electrode traces (Pitt \& Mosley, 1986).

Effects of calmidazolium ( $R 24571$ ) on sporulation. The calmodulin inhibitor R24571 was added to $30 \mathrm{~h}$ cultures, from $5 \mathrm{~mm}$ stock in DMSO, at $0-10 \mu \mathrm{M}$ concentration either $30 \mathrm{~min}$ before or $5 \mathrm{~min}$ after the addition of $\mathrm{Ca}^{2+}$ to $10 \mathrm{~mm}$ concentration. Growth characteristics and sporulation indices were subsequently determined (Pitt \& Poole, 1981).

Protein phosphorylation. Biomass $(1 \mathrm{ml}$ containing about $3 \mathrm{mg}$ dry wt) was removed, at timed intervals over $0-8 \mathrm{~h}$, from cultures $(32 \mathrm{~h})$ grown in the presence or absence of $\mathrm{Ca}^{2+}(10 \mathrm{~mm})$ to which $\mathrm{R} 24571$ $(5 \mu \mathrm{M})$ was added either before or after $\mathrm{Ca}^{2+}$. To each sample $44 \cdot 4 \mathrm{kBq}$ of ${ }^{32}$ P-labelled phosphoric acid was added $\left(7.4 \mathrm{GBq} \mathrm{mmol}^{-1}\right.$; Amersham) followed by incubation at $25^{\circ} \mathrm{C}$ for $20 \mathrm{~min}$. Samples were heated for $20 \mathrm{~min}$ on a boiling water bath, cooled, and cell walls removed by digestion for $4 \mathrm{~h}$ with Novozyme 234 to which the protease inhibitor aprotinin was added (Roncal et al., 1991). Protein was precipitated by the addition of cold $10 \%(\mathrm{w} / \mathrm{v})$ trichloroacetic acid $(2 \mathrm{ml})$ in $5 \mathrm{~mm}$ sodium phosphate followed by $15 \mathrm{~min}$ on a boiling water bath. Precipitated protein was collected on Whatman GFC glass filter pads and washed with $5 \%(\mathrm{w} / \mathrm{v})$ TCA $(5 \times 10 \mathrm{ml})$ in $5 \mathrm{~mm}$-sodium phosphate; ${ }^{32} \mathrm{P}$ was counted in a liquid scintillation counter.

Radioactive labelling for phosphoprotein analysis. Biomass was harvested from $32 \mathrm{~h}$ vegetative cultures by filtration and washed with phosphate-free growth medium $(5 \times 100 \mathrm{ml})$. Pads of mycelium $(1 \mathrm{~g}$ fresh wt) were resuspended in $25 \mathrm{ml}$ of medium and after treatments with $\mathrm{R} 24571(5 \mu \mathrm{M})$ or $\mathrm{Ca}^{2+}(10 \mathrm{mM})$, as appropriate, $7 \cdot 4 \mathrm{MBq}$ of ${ }^{32} \mathrm{P}$ (as $\mathrm{H}_{3} \mathrm{PO}_{4}$ ) was added before shaking for $2 \mathrm{~h}$. Mycelia were harvested by filtration, washed with phosphate-free medium $(5 \times 100 \mathrm{ml})$ and homogenized at $0{ }^{\circ} \mathrm{C}$ with glass powder, using a mortar and pestle, in $3 \mathrm{ml}$ of extraction medium $(0 \cdot 1 \mathrm{M}$-Tris $/ \mathrm{HCl}, \mathrm{pH} 7 \cdot 5$; sucrose, $0.25 \mathrm{M} ; \beta$ mercaptoethanol, $0.01 \%, \mathrm{v} / \mathrm{v}$; EDTA, $1.0 \mathrm{~mm}$; cysteine hydrochloride, $0.01 \%, \mathrm{v} / \mathrm{v}$; phenylmethylsulphonyl fluoride, $1.0 \mathrm{~mm}$ ). Homogenates were centrifuged for $2 \mathrm{~min}$ at $1000 \mathrm{~g}$ and proteins in the supernatant fluid fractions were precipitated by the addition of a chloroform/ methanol mixture $(2: 1, \mathrm{v} / \mathrm{v})$, removed by aspiration, washed and resuspended in isoelectric focusing (IEF) sample buffer. Proteins were separated by non-equilibrium $\mathrm{pH}$ gradient electrophoresis (O'Farrell et al., 1977) in IEF tube gels with $5 \%(\mathrm{v} / \mathrm{v})$ ampholytes, pH 5-7 (Pharmacia). The second dimension was run in gradient polyacrylamide slab gels (7.5-15\%, w/v) using the buffer system of Laemmli (1970) in a Bio-Rad Protean II apparatus and incorporating appropriate protein standards (Sigma; 30-200 kDa). Gels were then stained in $0.025 \%$ $(\mathrm{w} / \mathrm{v})$ Coomassie brilliant blue $\mathrm{R} 250$ in $25 \%(\mathrm{v} / \mathrm{v})$ propan-2-ol and $10 \%(\mathrm{v} / \mathrm{v})$ acetic acid followed by destaining in $10 \%(\mathrm{v} / \mathrm{v})$ acetic acid. Autoradiography of dried gels was done using flash-sensitized Fuji NIF RX medical X-ray film at $-70^{\circ} \mathrm{C}$ with intensifying screens.

Additionally, replicate unstained gels were treated for $30 \mathrm{~min}$ with $16 \%(\mathrm{w} / \mathrm{v}) \mathrm{TCA}$ at $25^{\circ} \mathrm{C}$, as described by Mannai \& Cozzone (1982), to confirm that ester-linked phosphopolypeptides rather than acid phosphates or acyl-linked phosphates were detected, and that these corresponded in position to stained proteins in the polyacrylamide gels.

Protein determinations. Soluble proteins were assayed by the method of Lowry. Percoll was precipitated from appropriate samples by addition of 20 vols acetone at $-20^{\circ} \mathrm{C}$ followed by centrifugation at $3000 \mathrm{~g}$ for $15 \mathrm{~min}$, with the protein assay applied to the pellet resuspended in distilled water (Ugalde \& Pitt, 1984).

Density measurements. These were done according to Pitt \& Stewart (1981) using an Abbe type refractometer.

Electron microscopy of fractions. Samples were processed and viewed according to Ugalde \& Pitt (1984).

\section{Results}

Determination of cytosolic free calcium concentration and the influence of external calcium

The small size of hyphae and protoplasts (about $2 \mu \mathrm{m}$ ) of $P$. notatum excluded micro-injection techniques and the use of $\mathrm{Ca}^{2+}$ micro-electrodes for the determination of $\left[\mathrm{Ca}^{2+}\right]_{\mathrm{c}}$. Initial attempts to measure $\left[\mathrm{Ca}^{2+}\right]_{\mathrm{c}}$ directly in mycelium suspensions of $P$. notatum using $\mathrm{Ca}^{2+}$-chelating fluorescent dyes encountered problems through aggregation of the biomass and the binding of the dye to wallbound calcium. Subsequent experiments used protoplast suspensions as a model system since their conidiation response to $\mathrm{Ca}^{2+}$ parallels that of cultures inoculated from conidia (Ugalde et al., 1990).

Attempts to measure $\left[\mathrm{Ca}^{2+}\right]_{\mathrm{c}}$ with the permeant esters indo-1-AM and fura-2-AM, over a range of internal and external $\mathrm{pH}(4 \cdot 0-7 \cdot 5)$ were unsuccessful since intracellular hydrolysis of these was minimal after $6 \mathrm{~h}$ incubation, by which time the protoplasts were deteriorating. Whilst the free acid, fura-2, did not enter protoplasts over a wide range of conditions, indo- 1 was taken up but, contrary to the findings of Kaile et al. (1992) 

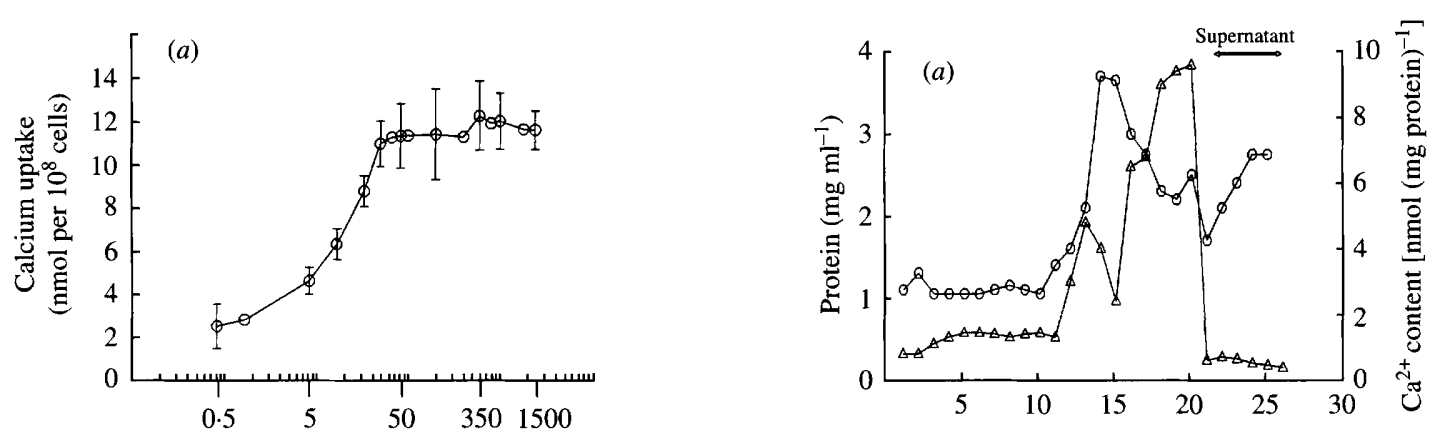

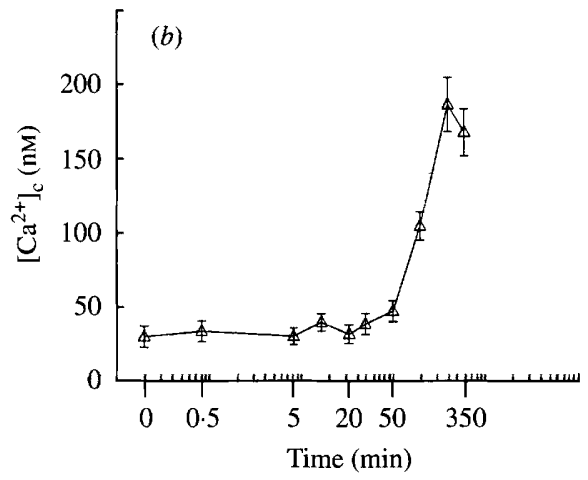

Fig. 1

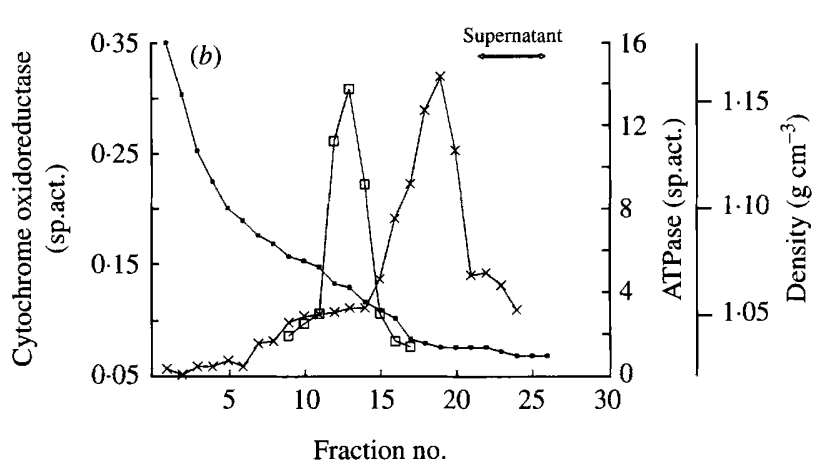

Fig. 2

Fig. 1. Calcium accumulation from $2.5 \mathrm{~mm}-\mathrm{Ca}^{2+}$ by protoplasts of $P$. notatum and the relationships to $\left[\mathrm{Ca}^{2+}\right]_{\mathrm{c}} \cdot\left(\right.$ a) $\mathrm{Ca}^{2+}$ uptake by protoplasts at $25{ }^{\circ} \mathrm{C}$ in the presence of $50 \mathrm{mM}$-glucose; $(b)\left[\mathrm{Ca}^{2+}\right]_{\mathrm{c}}$ of protoplasts during the period of $\mathrm{Ca}^{2+}$ uptake. Values are \pm sEM with three replicate determinations.

Fig. 2. Subcellular distribution patterns of marker enzymes and calcium in a silica sol (Percoll) density gradient fractionation of $36 \mathrm{~h}$ $\mathrm{Ca}^{2+}$-induced mycelium. (a) Location in fractions of ${ }^{45} \mathrm{Ca}(\triangle)$ and protein $(O) ;(b)$ location in fractions of cytochrome oxidase $(\square)$; ATPase $(\mathrm{X}) ; \boldsymbol{\square}$, density.

with protoplasts of Brassica napus, was not retained over the external $\mathrm{pH}$ range $3 \cdot 5-8 \cdot 5$. Consequently, the free acids and esters of indo- 1 and fura- 2 were deemed unsuitable for $\left[\mathrm{Ca}^{2+}\right]_{\mathrm{c}}$ determination in $P$. notatum.

Although protoplasts of $P$. notatum were impermeable to quin-2, quin-2-AM was useful for $\left[\mathrm{Ca}^{2+}\right]_{\mathrm{c}}$ determinations under certain conditions wherein the average cytosolic $\mathrm{pH}$ of protoplasts was manipulated by adjustments to the $\mathrm{pH}$ of the incubation medium. Since experiments with cytoplasmic carboxylic esterases separated on polyacrylamide gels showed minimal hydrolysis of quin-2-AM at $\mathrm{pH} 5.0$ whereas substantial activity occurred at $\mathrm{pH} 7 \cdot 0-8 \cdot 0$, the average internal $\mathrm{pH}$ of protoplasts was adjusted accordingly. As protoplasts were unstable at external $\mathrm{pH}$ values above 7.5 intracellular hydrolysis of the ester was routinely promoted by transfer, after loading with the ester at $\mathrm{pH} 5 \cdot 0$, into buffer at $\mathrm{pH} 7.5$ to generate an average internal $\mathrm{pH}$ of 7.2. Under these conditions the ester concentration within protoplasts reached $1.5 \mathrm{~mm}$ within $30 \mathrm{~min}$ at $25^{\circ} \mathrm{C}$ with a subsequent intracellular quin- 2 concentration of $0.8 \mathrm{~mm}$ calculated on the basis of a protoplast water content of $63.38 \%(\mathrm{w} / \mathrm{v})$. Thereafter, the external
$\mathrm{pH}$ was adjusted to $\mathrm{pH} 6.8$, generating an internal $\mathrm{pH}$ of $6 \cdot 8$, to maintain maximum cell stability for $\left[\mathrm{Ca}^{2+}\right]_{\mathrm{c}}$ determinations. An effective $K_{\mathrm{D}}$ for quin-2 of $258 \mathrm{~nm}$ was determined, at $25^{\circ} \mathrm{C}$ and $\mathrm{pH} 6.8$, for protoplasts containing $4.8 \mathrm{nmol} \mathrm{Mg}^{2+}(\mathrm{kg} \text { cell water })^{-1}$ and used in all calculations of $\left[\mathrm{Ca}^{2+}\right]_{\mathrm{c}}$.

Calcium accumulation from media containing $2.5 \mathrm{~mm}$ $\mathrm{Ca}^{2+}$ above the basal $\mathrm{Ca}^{2+}$ concentration $(3 \cdot 0-3 \cdot 3 \mu \mathrm{M})$, by protoplasts, and the relationship to $\left[\mathrm{Ca}^{2+}\right]_{\mathrm{c}}$ are shown in Fig. 1. Uptake of calcium was biphasic and involved an initial rapid binding to the membrane $\left(K_{\mathrm{D}} 3.02 \mathrm{mM}^{-\mathrm{Ca}^{2+}}\right.$; $Y_{\mathrm{t}} 1.97 \mathrm{nmol} \mathrm{Ca}^{2+}$ per $10^{8}$ cells), followed by an energy dependent transport displaying Michaelis-Menten kinetics $\left[K_{\mathrm{m}} 0.29 \mathrm{mM}^{-\mathrm{Ca}^{2+} ; V_{\max }} 0.67 \mathrm{nmol} \mathrm{m^{-1 }}\right.$ (mg dry $\mathrm{wt})^{-1}$. Although the concentration of average cell calcium in protoplasts increased rapidly from an initial resting value of about $2 \mu \mathrm{mol}$ to $50 \mu \mathrm{mol}(\mathrm{kg} \text { cell water })^{-1}$ during the $30 \mathrm{~min}$ period to attain the steady state of calcium uptake, the $\left[\mathrm{Ca}^{2+}\right]_{\mathrm{c}}$ remained largely unchanged at $30 \mathrm{~nm}$. Thereafter, whilst the steady state concentration of cell calcium remained unchanged, $\left[\mathrm{Ca}^{2+}\right]_{\mathrm{c}}$ increased to a maximum value of $185 \cdot 3 \pm 18 \cdot 4 \mathrm{~nm}$ between 2 and $6 \mathrm{~h}$. 
Table 1. $\left[\mathrm{Ca}^{2+}\right]_{c}$ of protoplasts extracted from $\mathrm{Ca}^{2+}$ induced mycelium at various times after addition of calcium chloride $(10 \mathrm{~mm})$

Mycelium was harvested at various times after addition of $\mathrm{Ca}^{2+}$, and washed for $3 \times 10 \mathrm{~s}$ in growth medium excluding $\mathrm{Ca}^{2+}$. Protoplasts were extracted (see Methods) and $\left[\mathrm{Ca}^{2+}\right]_{\mathrm{c}}$ was determined using the quin-2 method. Values are shown \pm SEM (with replicate determinations).

\begin{tabular}{|c|c|c|}
\hline $\begin{array}{l}\text { Time after } \mathrm{Ca}^{2+} \\
\text { addition }(\mathrm{h})\end{array}$ & Equivalent growth stage & $\begin{array}{c}{\left[\mathrm{Ca}^{2+}\right]_{\mathrm{c}} \text { of }} \\
\text { extracted } \\
\text { protoplasts (nM) }\end{array}$ \\
\hline 0 & Stage 1 , vegetative tips & $31 \cdot 6 \pm 3 \cdot 8(10)$ \\
\hline 0.5 & Stage 1 & $30 \cdot 3 \pm 3 \cdot 5(7)$ \\
\hline $2 \cdot 0^{*}$ & Stage 1 & $30 \cdot 6 \pm 3 \cdot 2(5)$ \\
\hline $4 \cdot 0$ & Stage 2 , branching of hyphae & $42 \cdot 1 \pm 4 \cdot 9(6)$ \\
\hline $6 \cdot 0$ & Stage 3 , first phialides formed & $128 \cdot 4 \pm 17 \cdot 3(6)$ \\
\hline $8 \cdot 0$ & Stage 4 , first spores formed & $181 \cdot 7 \pm 20 \cdot 2(10)$ \\
\hline $\begin{array}{l}\text { No additions of } \\
\mathrm{Ca}^{2+}\end{array}$ & Stage 1 , vegetative tips & $32 \cdot 6 \pm 4 \cdot 9(7)$ \\
\hline
\end{tabular}

* Steady state of $\mathrm{Ca}^{2+}$ uptake achieved.

A broadly similar pattern of change in values for $\left[\mathrm{Ca}^{2+}\right]_{\mathrm{c}}$ was recorded for protoplasts of $P$. notatum isolated from $\mathrm{Ca}^{2+}$-induced mycelium over the period of sporulation (Table 1). No significant changes in the basal $\left[\mathrm{Ca}^{2+}\right]_{\mathrm{c}}$ of $31 \cdot 6 \pm 3.8 \mathrm{nM}$ occurred up to attainment of the steady state of calcium uptake, confirmed as close to that found by Pitt et al. (1988) at 15.8 $\pm 3 \cdot 1 \mathrm{nmol}$ (mg dry $w t)^{-1}$, which corresponds to an average cell calcium concentration of $3 \cdot 1 \mathrm{mmol}(\mathrm{kg} \text { cell water })^{-1}$, and achieved in mycelium after $2 \mathrm{~h}$ exposure to $10 \mathrm{~mm}-\mathrm{CaCl}_{2}$. Thereafter, values determined at growth stages $1-4$ rose gradually (Table 1 ) to reach a constant maximum value for $\left[\mathrm{Ca}^{2+}\right]_{\mathrm{c}}$ of $181 \cdot 7 \pm 20 \cdot 2 \mathrm{nM}$ at the production of the first spores (stage 4).

Neither protoplasts nor mycelium preloaded to the steady state of uptake in the presence of $2.5 \mathrm{~mm}-\mathrm{Ca}^{2+}$ containing ${ }^{45} \mathrm{Ca}^{2+}$, and transferred to nominally $\mathrm{Ca}^{2+}$-free medium, showed significant efflux of ${ }^{45} \mathrm{Ca}^{2+}$ either in the presence or absence of Ins 1,4,5 $\mathrm{P}_{3}(2 \cdot 5-40 \mu \mathrm{M})$ or A23187 $(5 \mu \mathrm{M})$, singly or in combination throughout a $2 \mathrm{~h}$ period.

\section{Subcellular sites of calcium accumulation and its mobilization}

The subcellular distribution of $\mathrm{Ca}^{2+}$ was examined in organelles subfractionated from $36 \mathrm{~h}$ mycelium that had been preloaded with $\mathrm{Ca}^{2+}$ for $6 \mathrm{~h}$ by addition of $\mathrm{CaCl}_{2}$ $(2 \cdot 5-10 \mathrm{~mm})$ to $30 \mathrm{~h}$ vegetative cells. Distributions of mitochondria and microsomes in fractions were similar to those in P. cyclopium (Ugalde \& Pitt, 1984) using cytochrome oxidase and $\mathrm{H}^{+}$-ATPase markers with suitable inhibitors. Fig. 2 shows the distribution of marker enzymes for mitochondria (fractions 11-15) and microsomes (fractions 17-21) along with the subcellular locations of ${ }^{45} \mathrm{Ca}^{2+}$. These data and electron microscopy

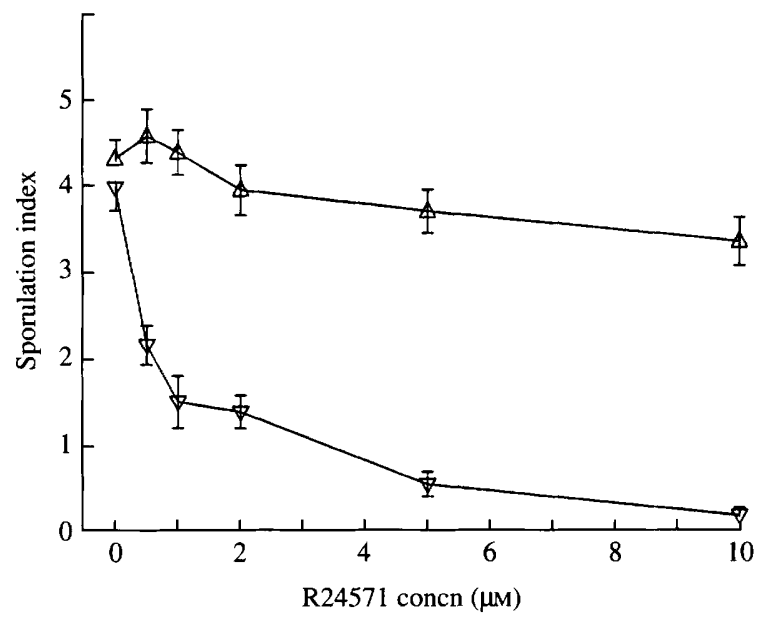

Fig. 4

Fig. 3. Dose-response relationships for $\mathrm{A} 23187$ effects on release of $\mathrm{Ca}^{2+}$ from pooled mitochondrial fractions (12-14) from $36 \mathrm{~h} \mathrm{Ca}{ }^{2+}-$ induced mycelium of $P$. notatum. Extra-organelle $\mathrm{Ca}^{2+}$ was monitored using $50 \mu \mathrm{M}$-quin-2, as described in the text, following doses of A23187. The inset exemplifies a fluorescence trace whereby calcium release from the mitochondrial preparation was measured as described in the text. A23187 $(2.5 \mu \mathrm{M})$ was added at $\downarrow$.

Fig. 4. Effects of calmidazolium (R24571) concentration on calcium-induced conidiation in P. notatum. Vegetative cultures were grown for $30 \mathrm{~h}$ in submerged aerated culture and the calmodulin antagonist (R24571) was added (a) 30 min after adding calcium to a $10 \mathrm{~mm}$ concentration $(\triangle)$, or $(b) 30$ min prior to the addition of calcium to a $10 \mathrm{~mm}$ concentration $(\nabla)$. Cultures were harvested after further growth for $48 \mathrm{~h}$ and the sporulation indices were determined. Values are \pm SEM with three replicate determinations. 


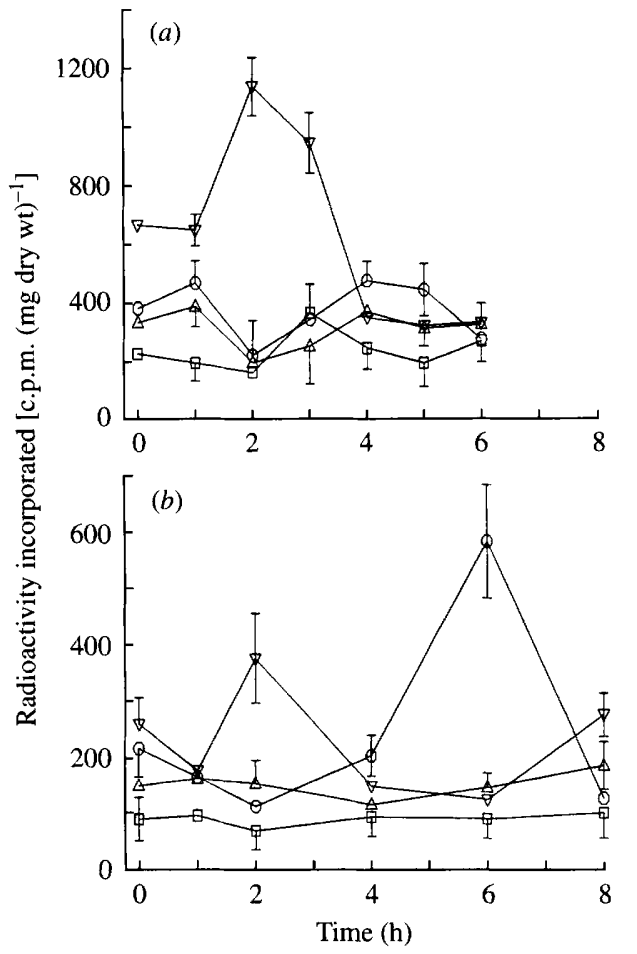

Fig. 5. Rate of ${ }^{32} \mathrm{P}$ incorporation by initially $32 \mathrm{~h}$ mycelium of $P$. notatum in the presence or absence of calcium (10 mM) with R24571 $(5 \mu \mathrm{M})$ added (a) $30 \mathrm{~min}$ before or (b) $5 \mathrm{~min}$ after calcium treatment. At the times indicated mycelium samples $(1 \mathrm{ml})$ were pulse-labelled with $\mathrm{H}_{3}{ }^{32} \mathrm{PO}_{4}$ for $20 \mathrm{~min}$ at $25^{\circ} \mathrm{C}$ and hot-trichloroacetic acid-precipitable counts determined as in the text. The following are shown: effect of R24571 in the absence of $\mathrm{Ca}^{2+}(\square)$; R24571 in the presence of calcium $(\triangle)$; calcium alone $(\nabla)$; without both calcium and R24571 (O). Values are \pm SEM with three replicate determinations.

observations showed calcium was principally associated with the mitochondria and microsomes. The latter, in this preparation, contained substantial elements of the ER and Golgi, as determined by the respective enzyme markers, cytochrome $c$ oxidoreductase and latent IDPase, in addition to plasmalemma components. In the present case, particular interest centred on vacuolar components of the microsomes following reports of vacuolar locations of $\mathrm{Ca}^{2+}$ in Neurospora (Cornelius \& Nakashima, 1987; Cornelius et al., 1989). Since the microsomal fractions (Fig. 2) only contained vesicles less than $100 \mathrm{~nm}$ in diameter, larger vacuoles up to $1 \mu \mathrm{m}$ were isolated from mycelium by a composite method developed from those of Cornelius \& Nakashima (1987). The vacuolar pellet so derived from mycelium of $P$. notatum was rich in azide- $(5 \mathrm{~mm})$ and vanadate- $(1 \mathrm{mM})$ insensitive ATPase activity [152.7 $\mu \mathrm{g} \mathrm{Pi} \mathrm{min}{ }^{-1}$ (mg protein $\left.)^{-1}\right]$ and contained significant levels of $\mathrm{Ca}^{2+}[49 \cdot 5$ nmol (mg protein $)^{-1}$.

Plasma membrane vesicles were prepared from protoplasts by differential centrifugation and partitioning in an aqueous two-phase polymer system (Ugalde, 1991).
Such vesicles showed vanadate-sensitive $(100 \mu \mathrm{M}) \mathrm{H}^{+}$-

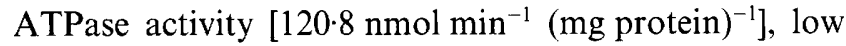
levels of Golgi-derived components as indicated by IDPase activity $\left[1.3 \mathrm{nmol} \mathrm{min}{ }^{-1}(\mathrm{mg} \text { protein })^{-1}\right]$ and minimal contamination with ER-derived elements as shown by negligible activity of NADPH cytochrome $c$ oxidoreductase. Preparations of plasma membrane vesicles $(0 \cdot 1-1.0 \mu \mathrm{m})$ from protoplasts derived from mycelium grown in the presence of $10 \mathrm{mM}^{45} \mathrm{Ca}^{2+}$ contained $2 \cdot 6 \pm 1 \cdot 2(9) \mathrm{nmol} \mathrm{Ca}^{2+}$ (mg protein) ${ }^{-1}$. Vesicles from mycelium grown in nominally $\mathrm{Ca}^{2+}$-free medium (containing about $2 \mu \mathrm{M}-\mathrm{Ca}^{2+}$ present in the ingredients) showed no $\mathrm{Ca}^{2+}$ detectable by atomic absorption spectroscopy.

Calcium-containing subcellular fractions obtained from Percoll gradients along with vacuoles and plasmalemma vesicles, separated by differential centrifugation and partitioning methods, respectively, were subjected to Ins $1,4,5 \mathrm{P}_{3}$ and $\mathrm{A} 23187$, which are treatments known to release calcium from subcellular stores in a variety of cells.

Since initial experiments showed that low density fractions from Percoll gradients required prolonged high-speed centrifugation ( $75000 \mathrm{~g}$ for $30 \mathrm{~min}$ ) to achieve sedimentation, such methods proved unsuitable for measuring rapid release of ${ }^{45} \mathrm{Ca}^{2+}$. Calcium-sensitive micro-electrodes containing the neutral ionophore ETH 1001 (Clapper \& Lee, 1985) also proved unsatisfactory due to the artefact created by the addition of ATP (Dawson et al., 1986). Consequently, efflux of $\mathrm{Ca}^{2+}$ from organelles in suspension was monitored using quin-2, but the use of fura-2 (Cornelius et al., 1989) was precluded by the levels of free calcium in suspensions which exceeded the sensitivity range of the dye. Quin-2 concentrations within the $10-50 \mu \mathrm{M}$ range permitted measurement of released free calcium in the $200 \mathrm{~nm}$ range. After each experiment, the quin-2 response to changes in $\mathrm{Ca}^{2+}$ concentration was calibrated by the addition to aliquot equivalents, lacking Ins $1,4,5 \mathrm{P}_{3}$ or A23187 additions, of known amounts of $\mathrm{Ca}^{2+}$. In practice, the addition of $10 \mathrm{nmol} \mathrm{Ca}{ }^{2+}$ to $2 \mathrm{ml}$ of diluted homogenate resulted in a free calcium concentration change of $\sim 300 \mathrm{nM}$, which was much lower than the theoretical change $(5 \cdot 6 \mu \mathrm{M})$ expected in the absence of endogenous buffering that arose from non-specific binding of quin-2 to unknown components in the fractions.

None of the fractions obtained from $36 \mathrm{~h} \mathrm{Ca}^{2+}$-induced mycelium (Fig. 2) released associated calcium on treatment with Ins $1,4,5 \mathrm{P}_{3}$ over the ranges $2 \cdot 5-5 \mu \mathrm{M}$ and 4-40 $\mathrm{M}$. Likewise, membrane-bound $\mathrm{Ca}^{2+}$ associated with plasma membrane vesicles or vacuoles was not mobilized over the same concentration ranges of Ins $1,4,5 \mathrm{P}_{3}$. However, each of fractions 11-15, which were rich in mitochondria showing good respiratory control 


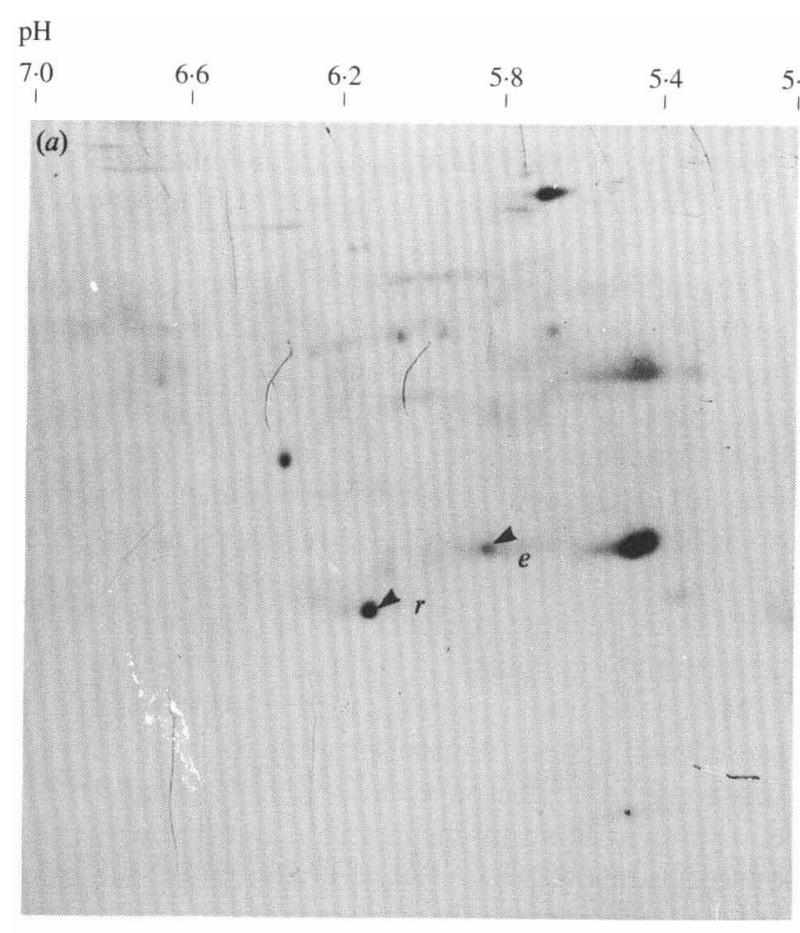

$$
\begin{gathered}
5 \cdot 0 \\
1
\end{gathered}
$$
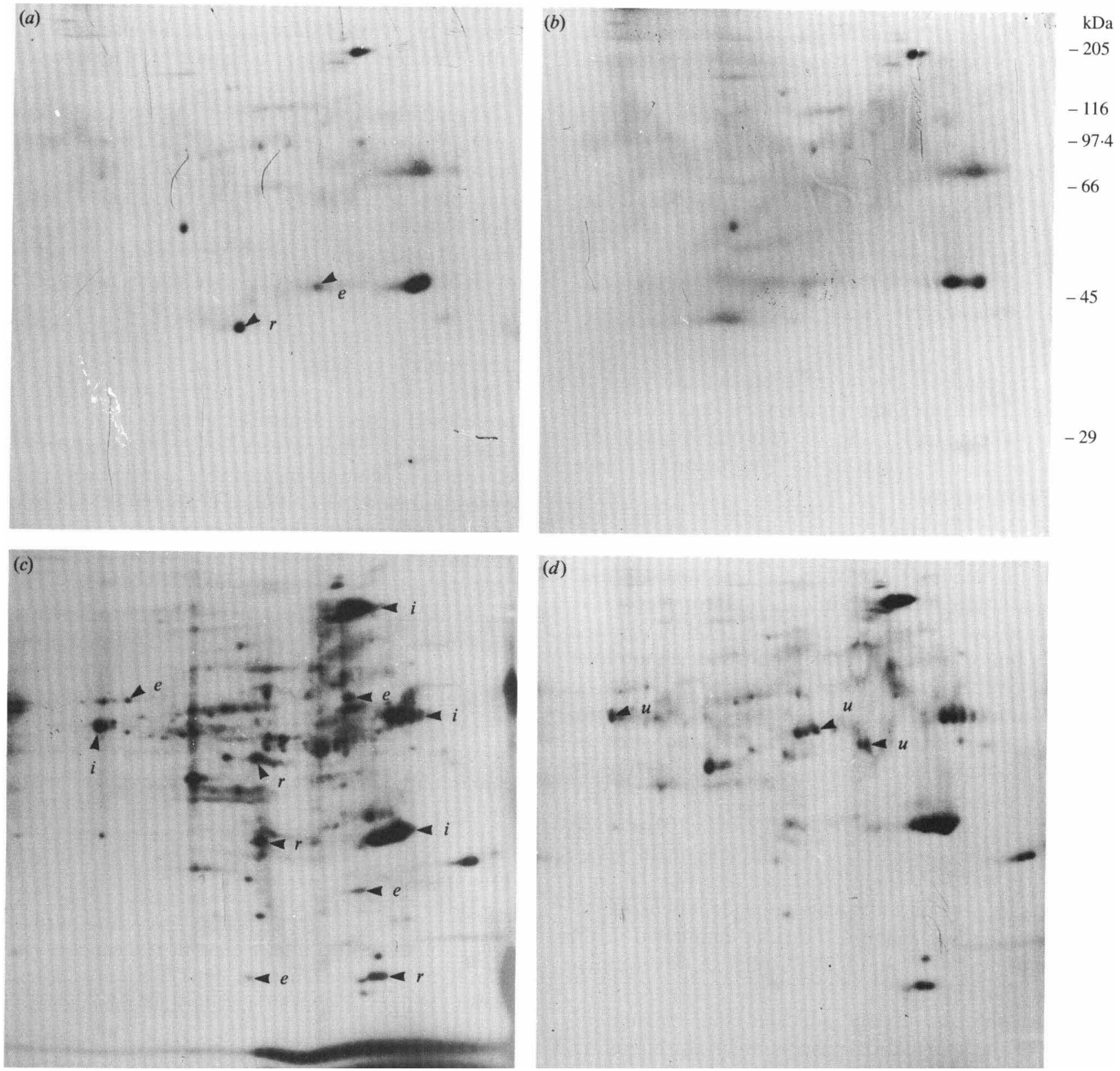

Fig. 6. Autoradiographs of two-dimensional SDS-PAGE gels of ${ }^{32} \mathrm{P}$-labelled phosphoproteins from initially $32 \mathrm{~h}$ vegetative submerged aerated cultures of $P$. notatum subsequently untreated or treated with $\mathrm{R} 24571(5 \mu \mathrm{M})$ and $\mathrm{Ca}^{2+}(10 \mathrm{mM})$. (a) Untreated vegetative mycelium; $(b)$ vegetative mycelium to which R24571 was added; $(c)$ mycelium induced by the addition of $\mathrm{Ca}^{2+}(10 \mathrm{~mm})$ at $32 \cdot 5 \mathrm{~h} ;(d)$ as (c), but to which $\mathrm{R} 24571$ was added $30 \mathrm{~min}$ prior to $\mathrm{Ca}^{2+}$ addition. All treatments were synchronized at $32.5 \mathrm{~h}$ and labelled with $\mathrm{H}_{3}{ }^{32} \mathrm{PO}_{4}$ for a period of $2 \mathrm{~h}$ before harvesting and processing as in the text.

on pyruvate (Pitt \& Mosley, 1986), released 33-50\% of their associated calcium in the presence of A23187 at $2-5 \mu \mathrm{M}$ concentrations (Fig. 3). Calcium was not released from other fractions from Percoll gradients nor from preparations of membrane vesicles or vacuoles. No release of calcium was detected from any organelle fraction obtained from vegetative cells.
Effects of the anti-calmodulin agent calmidazolium ( $R 24571)$ on calcium-induced sporulation

The putative rôle of calmodulin in signalling sequences relating to $\mathrm{Ca}^{2+}$ fluxes mediated by the mitochondria was examined using the anti-calmodulin drug R24571.

Initial experiments showed the R24571 added before, 
with, or 1-5 min after calcium addition had no significant effect on $\mathrm{Ca}^{2+}$ uptake by $P$. notatum within the range (5-20 $\mu \mathrm{M})$ effective for calmodulin interactions. Fig. 4 shows the profound reduction in sporulation promoted by $\mathrm{R} 24571$ at concentrations above $0.5 \mu \mathrm{M}$ when added $30 \mathrm{~min}$ prior to $\mathrm{Ca}^{2+}$ addition $(10 \mathrm{~mm})$. When $10 \mathrm{~mm}$ $\mathrm{Ca}^{2+}$ was added before $\mathrm{R} 24571$ the reduction in the level of sporulation was relatively small (Fig. 4).

Separate experiments showed that a minimum time of 5 min need elapse between additions of $\mathrm{R} 24571$ and $\mathrm{Ca}^{2+}$ to achieve maximum reduction of sporulation with a $5 \mu \mathrm{M}$ concentration of the drug.

\section{Protein phosphorylation during calcium-induced sporulation}

As a consequence of the observation that early events involving $\mathrm{Ca}^{2+}$ binding and uptake were least dependent on calmodulin mediation, the rôle of protein phosphorylation in subsequent stages of $\mathrm{Ca}^{2+}$-induction of sporulation was examined.

Fig. 5(a) shows the effects of $5 \mu \mathrm{M}-\mathrm{R} 24571$ added to $32 \mathrm{~h}$ vegetative cultures of $P$. notatum which were subsequently made $10 \mathrm{mM}$ with $\mathrm{Ca}^{2+}$ at various times after the addition of the calmodulin inhibitor. Vegetative cultures, to which calcium was not added, showed relatively minor peaks of protein phosphorylation over the time-course, which were reduced by R24571. Calcium-induced cultures displayed massive novel protein phosphorylation at $2 \mathrm{~h}$ which was eliminated by $\mathrm{R} 24571$, accompanied by moderate reductions in the $1 \mathrm{~h}$ and $4-6 \mathrm{~h}$ phosphorylations.

In similar experiments in which $\mathrm{Ca}^{2+}(10 \mathrm{~mm})$ was added 5 min before R24571, a combination in which sporulation was only slightly reduced (see Fig. $4 a, b$ ), a much smaller peak of calmodulin-dependent phosphorylations was found and the 4-6 h peak eliminated in the presence of both $\mathrm{Ca}^{2+}$ and $\mathrm{R} 24571$ relative to vegetative cultures (Fig. $5 b$ ).

Because the above data indicated that calcium induction of the sporulation process involved differential modulations in protein phosphorylations mediated by calmodulin, the qualitative changes in these were examined using two-dimensional electrophoresis (SDSPAGE).

\section{Two-dimensional SDS-PAGE analysis of phosphoproteins during $\mathrm{Ca}^{2+}$-induced conidiation}

Since experiments on the rate of ${ }^{32} \mathrm{P}$ incorporation during $\mathrm{Ca}^{2+}$-induced conidiation showed substantial quantitative increases in calmodulin-dependent protein phosphorylation at $2 \mathrm{~h}$, the phosphorylation/ dephosphorylation status of proteins was examined during this period. Only those phosphorylations co- inciding with stained proteins were considered and showed substantial qualitative and quantitative changes during the stage of morphogenesis which relates to the onset of branching (Stage 2) and which precedes phialide differentiation (Stage 3), as defined in P. notatum (Pitt \& Mosley, 1985b).

Vegetative cells showed some protein phosphorylations (Fig. 6a), but whether these were calciumindependent or mediated by the basal level of $\mathrm{Ca}^{2+}$ in the medium $(2 \mu \mathrm{M})$ was not determinable. However, since these were, in some cases, either eliminated (marked as $e$; Fig. $6 a$ ) or reduced (marked as $r$; Fig. $6 a$ ) in the presence of R24571 (Fig. $6 b$ ) the indications are that some calmodulin-independent activity occurs in vegetative cells even in the presence of a minimal $\mathrm{Ca}^{2+}$ concentration.

Many additional proteins were phosphorylated in the presence of added $10 \mathrm{mM}^{-\mathrm{Ca}^{2+}}$ (Fig. $6 c$ ) with some of the relatively few phosphorylations associated with vegetative cells being intensified (e.g. marked as $i$; Fig. $6 c$ ) by addition of the ion. Whilst several of the calciuminduced phosphorylations were reduced (e.g. marked as $r$; Fig. $6 c$ ) and eliminated (marked as $e$; Fig. $6 c$ ) by R24571 (Fig. 6d), which indicated calmodulin dependence (cf. Fig. $6 c, d$ ), others remained unaffected by the drug (marked as $u$; Fig. $6 d$, cf. Fig. $6 c$ ) even though their phosphorylation/dephosphorylation status may be changed by the addition of $10 \mathrm{mM}-\mathrm{Ca}^{2+}$ (cf. Fig. $6 a, b$ ). This implies some element of protein C-kinase regulation of protein phosphorylation, in addition to that which is calmodulin-dependent, in both vegetative and $\mathrm{Ca}^{2+}$ induced cells.

\section{Discussion}

Cytoplasmic $\mathrm{Ca}^{2+}$ has emerged as an intracellular regulator of central importance in transducing external stimuli in animals (Berridge, 1987) and more recently in plants (Knight et al., 1991). Although the evidence for a second messenger function for $\mathrm{Ca}^{2+}$ in fungi is mounting and a rôle for the ion in morphogenesis is established (Elliott, 1986; Pitt \& Kaile, 1990; Brunton \& Gadd, 1991; Gadd \& Brunton, 1992) measurements of $\left[\mathrm{Ca}^{2+}\right]_{c}$ remain difficult in these organisms owing to the small size and vacuolate nature of cells. Technical problems relating to permeability also prevail which limit the value in fungi of fluorescent $\mathrm{Ca}^{2+}$ chelating dyes which were designed essentially for use with animal systems (Tsien $e t$ al., 1982) and which can themselves perturb $\left[\mathrm{Ca}^{2+}\right]_{c}$ under certain conditions (Rink \& Pozzan, 1985). Notwithstanding these difficulties Miller \& Sanders (1989) measured $\left[\mathrm{Ca}^{2+}\right]_{\mathrm{c}}$ at $92 \mathrm{~nm}$ in $N$. crassa, grown in media containing $1 \mathrm{~mm}-\mathrm{Ca}^{2+}$, using $\mathrm{Ca}^{2+}$-selective micro-electrodes, and Pitt \& Kaile (1990) have estimated values 
of $15-80 \mathrm{~nm}$ in $P$. notatum using quin-2, which both approximate to values originally obtained for plants (Gilroy et al., 1986). Whilst the present work proscribed the use of fura- 2 and indo- 1 the quin- 2 method was refined to maximize uptake of the permeant ester at low $\mathrm{pH}$ followed by enhancement of its hydrolysis by promotion of an internal $\mathrm{pH}$ shift into the weakly alkaline range. Early transient changes in $\left[\mathrm{Ca}^{2+}\right]_{\mathrm{c}}$ were not a feature of rapid biphasic uptake of the ion by protoplasts from $2.5 \mathrm{mM}^{-\mathrm{Ca}^{2+}}$, nor of protoplasts isolated from mycelium exposed to calcium even when the average cell calcium concentration increased 25 -fold and 50 -fold, respectively, and corresponded to average cell calcium concentrations three orders of magnitude greater than $\left[\mathrm{Ca}^{2+}\right]_{\mathrm{c}}$ achieved at the steady state of $\mathrm{Ca}^{2+}$ accumulation. This response and the subsequent gradual increase in $\left[\mathrm{Ca}^{2+}\right]_{\mathrm{c}}$ over several hours may imply that any initial calmodulin-dependence could involve sensitivity modulation where the affinity of a $\mathrm{Ca}^{2+}$-calmodulin response element may increase without a prior increase in $\left[\mathrm{Ca}^{2+}\right]_{c}$ followed by an amplitude response which might be related to increased $\left[\mathrm{Ca}^{2+}\right]_{c}$.

Although the vacuoles of yeasts (Anraku et al., 1991) and other fungi (Miller et al., 1990) store $\mathrm{Ca}^{2+}$, and Cornelius \& Nakashima (1987) consider those of some strains of $N$. crassa regulate $\mathrm{Ca}^{2+}$ homeostasis under the influence of Ins $1,4,5 \mathrm{P}_{3}$ (Cornelius et al., 1989), the mitochondria served as a major subcellular store of mobile $\mathrm{Ca}^{2+}$ in $P$. notatum and were not influenced by Ins $1,4,5 \mathrm{P}_{3}$. The release of mitochondrial $\mathrm{Ca}^{2+}$ promoted by the calcium ionophore A23187 agrees with the experimental findings of Borle \& Struder (1978) in liver and kidney and is consistent with the view from mammalian systems that mitochondria play some rôle in regulating cellular calcium homeostasis (Prentki et al., 1983) in addition to the ER under the primary control of Ins 1,4,5 $\mathrm{P}_{3}$ (Streb et al., 1983). At present, there is no evidence from fungi which implicates Ins $1,4,5 \mathrm{P}_{3}$ in the release of $\mathrm{Ca}^{2+}$ from elements of the ER.

Whilst $\mathrm{Ca}^{2+}$-mediated signalling events are generally accompanied by early transient changes in $\left[\mathrm{Ca}^{2+}\right]_{\mathrm{c}}$ in animal systems, accumulation of $\mathrm{Ca}^{2+}$ and changes in $\left[\mathrm{Ca}^{2+}\right]_{\mathrm{c}}$ are temporally separated in $P$. notatum with the latter coinciding with re-routing of carbohydrate catabolism from an EMP/TCA (Embden-MeyerhofParnas/tricarboxylic acid) driven system to one based on gluconate metabolism where ED/PP (EntnerDoudoroff/pentose phosphate) and related pathways prevail linked through a modified TCA 'half-cycle' akin to that in the pseudomonads (Pitt \& Mosley, 1986). Although current opinions tend to favour the view that the increased $\left[\mathrm{Ca}^{2+}\right]_{\mathrm{c}}$ could affect such $\mathrm{Ca}^{2+}$-dependent metabolic changes, presumably via putative signalling routes analagous to those in animals, the pivotal biochemical rôle of the mitochondria in $\mathrm{Ca}^{2+}$-induced sporulation in P. notatum (Pitt \& Mosley, 1986) lends support to an alternative interpretation arising from the present findings of mitochondria as the primary store of mobile cell $\mathrm{Ca}^{2+}$. As Miller \& Sanders (1989) provide evidence that calcium homeostasis in Neurospora depends on ATP availability and since the ATP pool and adenylate energy charge only increase late during $\mathrm{Ca}^{2+}$ induced sporulation in P. notatum (Mosley et al., 1989), it could be maintained that elevated $\left[\mathrm{Ca}^{2+}\right]_{c}$ is a consequence of initial changes in mitochondrial function, and related respiratory activity, as $\mathrm{Ca}^{2+}$ is sequestered (Pitt \& Mosley, 1986). Limited ATP availability could restrict the capacity of mitochondria to contain the result of massive $\mathrm{Ca}^{2+}$ influx, or to regulate release of the ion from replete mitochondrial stores, accompanied by a consequential rise in $\left[\mathrm{Ca}^{2+}\right]_{c}$ which might subsequently influence $\mathrm{Ca}^{2+}$-sensitive glycolytic enzymes of the cytoplasm, e.g. EMP and ED. The growth check associated with the $\mathrm{Ca}^{2+}$-induced process could thereby be a consequence of reduced carbon flow, manifesting as metabolic starvation and initial ATP depletion, until rerouting permitted gluconate utilization. The time-course of $\mathrm{Ca}^{2+}$ uptake and the changes in $\mathrm{Ca}^{2+}$ homeostasis in the present work, and metabolic events associated with the process (Pitt \& Mosley, 1985a, b, 1986), are consistent with this view.

Irrespective of which mechanisms control homeostasis, pulse-labelling experiments revealed modulation in the rate of ${ }^{32} \mathrm{P}$ incorporation into phosphorylated proteins during $\mathrm{Ca}^{2+}$-induced sporulation. Since vegetative cells were, perforce, grown in the presence of minimal basal levels of calcium (about $2 \mu \mathrm{M}$ ) associated with components of the medium it was impossible to determine whether phosphorylations so occurring were $\mathrm{Ca}^{2+}$ mediated or not. However, analysis by SDS-PAGE indicated several protein phosphorylations which, within the limits of the pharmacological approach, were independent of calmodulin regulation whereas at least one protein was calmodulin-dependent even at $\left[\mathrm{Ca}^{2+}\right]_{c}$ orders of magnitude lower than that required to promote sporulation. Since the quantitative and qualitative patterns of protein phosphorylation and sporulation response to $\mathrm{Ca}^{2+}$ were both modified by $\mathrm{R} 24571$, the implication is that $\mathrm{Ca}^{2+}$-calmodulin-dependent kinases are important in conidiation. Substitution for trifluoperazine and ophiobolin A, as previously used to block calmodulin function (Pitt \& Kaile, 1990), by R24571, which is believed more specifically to block the calmodulin branch rather than the protein C-kinase branch of signal transduction (Gietzen, 1981; St Leger et al., 1989), strengthens evidence for significant calciumdependent calmodulin-independent protein phosphorylations during sporulation in P. notatum. This is consistent 
with the findings of Favre \& Turian (1987) in N. crassa and extends the initial observations by Pitt \& Kaile (1990) using phorbol esters, which substitute for 1,2diacylglycerol, that the protein $\mathrm{C}$-kinase branch may also be relevant to sporulation in P. notatum. However, molecular studies using in vitro systems would be necessary to extend the current conclusions.

Whilst there is some preliminary and indirect evidence for the existence of an inositol lipid based signalling system in fungi (Pitt \& Kaile, 1990; Brunton \& Gadd, 1991) and speculation that this may be mediated through elevated $\left[\mathrm{Ca}^{2+}\right]_{c}$, via $\mathrm{Ca}^{2+}$ influx rather than release from internal stores in yeast (Iida et al., 1990), the present work primarily implicates the mitochondrial stores in those protein phosphorylations manifesting during $\mathrm{Ca}^{2+}$ induced conidiation in P. notatum. However, these events seem temporally distinct from those which may be associated with the irreversible stages of $\mathrm{Ca}^{2+}$-induction promoted by brief (i.e. $30 \mathrm{~s}-2 \mathrm{~min}$ ) exposure to $\mathrm{Ca}^{2+}$ described by Ugalde \& Pitt (1986) for mycelium and protoplasts (Ugalde et al., 1990) of $P$. cyclopium. Whilst similar rapid binding occurred in $P$. notatum it was unaccompanied by measurable calcium influx or elevation of $\left[\mathrm{Ca}^{2+}\right]_{\mathrm{c}}$. Further work is necessary to determine the nature of any qualitative changes in phosphorylations of proteins which may be associated with the initial $\mathrm{Ca}^{2+}$ binding phase and the relevance to subsequent conidiation events.

Although recent observations in yeast have implicated $\mathrm{Ca}^{2+}$ in mediating protein kinase activity in integration of cellular responses to mating pheromone (Miyakawa et al., 1989), and a $16 \mathrm{kDa}$ protein has been identified as an endogenous substrate of a $\mathrm{Ca}^{2+}$-calmodulin-dependent protein kinase in Fusarium oxysporum (Hoshino et al., 1992), the specific proteins undergoing phosphorylations in $P$. notatum have yet to be identified. The possibility that phosphorylation/dephosphorylation mechanisms of those respiratory enzymes which are key targets during $\mathrm{Ca}^{2+}$-induction of sporulation in $P$. notatum (Pitt \& Mosley, 1985a, $b, 1986$ ) may be amongst endogenous substrates for $\mathrm{Ca}^{2+}$-regulated protein kinases warrants further investigation.

\section{References}

Anraku, Y., Ohya, Y. \& IIDa, H. (1991). Cell cycle control by calcium and calmodulin in Saccharomyces cerevisiae. Biochimica et Biophysica Acta 1093, 169-177.

BERRIDGE, M. J. (1987). Inositol trisphosphate and diacylglycerol: two interacting second messengers. Annual Review of Biochemistry 56, 159-193.

BERRIDGE, M. J. \& IRvine, R. F. (1984). Inositol trisphosphate, a novel second messenger in cellular signal transduction. Nature, London 312, 315-321.

Borle, A. B. \& Struder, B. (1978). Effects of calcium ionophores on the transport and distribution of calcium in isolated cells and in liver and kidney slices. Journal of Membrane Biology 38, 51-58.
Bowman, E. J. (1983). Comparison of the vacuolar membrane ATPase of Neurospora crassa with the mitochondrial and plasma membrane ATPases. Journal of Biological Chemistry 258, 15238-15244.

Bowman, E. J., Bowman, B. J. \& Slayman, C. W. (1981). Isolation and characterization of plasma membranes from wild type Neurospora crassa. Journal of Biological Chemistry 256, 12336-12342.

Bowman, B. J., Borgeson, C. E. \& Bowman, E. J. (1987). Composition of Neurospora crassa vacuolar membranes and comparison to endoplasmic reticulum, plasma membranes, and mitochondrial membranes. Experimental Mycology 11, 197-205.

BRunton, A. H. \& GADD, G. M. (1991). Evidence for an inositol lipid signal pathway in the yeast-mycelium transition of Ophiostoma ulmi, the Dutch elm disease fungus. Mycological Research 95, 484-491.

Clapper, D. L. \& LeE, H. C. (1985). Inositol trisphosphate induces calcium release from non-mitochondrial stores in sea urchin egg homogenates. Journal of Biological Chemistry 260, 13947-13954.

CoOperstein, S. J. \& Lazarow, A. (1951). A microspectrophotometric method for the determination of cytochrome oxidase. Journal of Biological Chemistry 189, 665-670.

Cornelius, G. \& Nakashima, H. (1987). Vacuoles play a decisive role in calcium homeostasis in Neurospora crassa. Journal of General Microbiology 133, 2341-2347.

Cornelius, G., Gebauer, G. \& Techel, D. (1989). Inositol trisphosphate induces calcium release from Neurospora crassa vacuoles. Biochemical and Biophysical Research Communications 162, 852-856.

Cramer, C. L., Ristow, J. L., Paulus, T. J. \& Davis, R. H. (1983). Methods for mycelial breakage and isolation of mitochondria and vacuoles of Neurospora. Analytical Biochemistry 128, 384-392.

Dawson, A. P., Comerford, J. G. \& Fulton, D. V. (1986). The effect of GTP on inositol 1,4,5-trisphosphate-stimulated $\mathrm{Ca}^{2+}$ efflux from a rat liver microsomal fraction. Biochemical Journal 234, 311-315.

Elliotr, C. G. (1986). Inhibition of reproduction by Phytophthora by calmodulin-interacting compounds trifluoperazine and ophiobolin A. Journal of General Microbiology 132, 1781-1785.

Favre, B. \& Turian, G. (1987). Identification of a calcium- and phospholipid-dependent protein kinase (protein kinase C) in Neurospora crassa. Plant Science 49, 15-21.

Fiske, C. H. \& SubbaRow, Y. (1925). The colorimetric determination of phosphorus. Journal of Biological Chemistry 66, 375-400.

FreEDMAN, M. H. \& RAFF, M. C. (1975). Induction of increased calcium uptake in mouse $\mathrm{T}$ lymphocytes by concanavalin $\mathrm{A}$ and its modulation by cyclic nucleotides. Nature, London 225, 378-382.

GadD, G. M. \& Brunton, A. H. (1992). Calcium involvement in dimorphism of Ophiostoma ulmi, the Dutch elm disease fungus, and characterization of calcium uptake by yeast cells and germ tubes. Journal of General Microbiology 138, 1561-1571.

Gietzen, K., Wüthrich, A. \& Bader, H. (1981). R24571: a new powerful inhibitor of red blood cell $\mathrm{Ca}^{2+}$-transport ATPase and of calmodulin-regulated functions. Biochemical and Biophysical Research Communications 101, 418-425.

Gilroy, S., Hughes, W. A. \& Trewavas, A. J. (1986). The measurement of intracellular calcium levels in protoplasts from higher plant cells. FEBS Letters 199, 217-222.

Gomes, S. L., Mennucci, L. \& Maia, J. C. C. (1979). A calcium dependent protein activator of mammalian cyclic nucleotide phosphodiesterase from Blastocladiella emersonii. FEBS Letters 99, $39-42$.

Hadley, G. \& Harrold, C. E. (1958a). The sporulation of Penicillium notatum Westling in submerged liquid culture. I. The effects of calcium and nutrients on sporulation. Journal of Experimental Botany 9, 408-417.

Hadley, G. \& Harrold, C. E. (1958b). The sporulation of Penicillium notatum Westling in submerged liquid culture. II. The initial sporulation phase. Journal of Experimental Botany 9, 418-425.

Hodges, T. K. \& LeONard, R. T. (1974). Purification of a plasmamembrane-bound adenosine triphosphatase from plant roots. Methods in Enzymology 32, 392-407.

Hoshino, T., Mizutani, A., Hidaka, H. \& Yamane, T. (1992). Identification of $\mathrm{Ca}^{2+} /$ calmodulin-dependent protein-kinase and endogenous substrate of Fusarium oxysporum. FEMS Microbiology Letters 94, 27-30.

Iida, H., YaGaWA, Y. \& ANRAKU, Y. (1990). Essential rôle for induced 
$\mathrm{Ca}^{2+}$ influx followed by $\left[\mathrm{Ca}^{2+}\right]_{\mathrm{i}}$ rise in maintaining viability of yeast cells late in the mating pheromone response pathway. Journal of Biological Chemistry 265, 13391-13399.

Kaile, A., Pitt, D. \& Kunn, P. J. (1992). Calcium cytotoxicity, protoplast viability and the rôle of calcium in soft-rot of Brassica napus due to Botrytis cinerea Pers. Physiological and Molecular Plant Pathology 40, 49-62.

Knight, M. R., Campbell, A. K., Smith, S. M. \& Trewavas, A. J. (1991). Transgenic plant aequorin reports the effects of touch and cold-shock and elicitors on cytoplasmic calcium. Nature, London 352, 524-526

LaEMmL., U. K. (1970). Cleavage of structural proteins during the assembly of the head of bacteriophage T4. Nature, London 277 , 680-685.

Mannal, M. \& Cozzone, A. J. (1982). Endogenous protein phosphorylation in Escherichia coli extracts. Biochemical and Biophysical Research Communications 107, 981-988.

Miller, A. J. \& Sanders, D. (1989). The energetics of cytosolic calcium homeostasis in fungal cells. Plant Physiology and Biochemistry 27, 551-556.

Miller, A. J., VogG, G. \& Sanders, D. (1990). Cytosolic calcium homeostasis in fungi: rôles of plasma membrane transport and intracellular sequestration of calcium. Proceedings of the National Academy of Sciences of the United States of America 87, 9348-9352.

Miyakawa, T., Youichi, O., Tsuchiya, E. \& Fukui, S. (1989). Saccharomyces cerevisiae protein kinase dependent on $\mathrm{Ca}^{2+}$ and calmodulin. Journal of Bacteriology 171, 1417-1422.

Mosley, M. J., Pitt, D. \& Barnes, J. C. (1989). Adenine and pyridine nucleotide levels during calcium-induced conidiation in Penicillium notatum. Antonie van Leeuwenhoek 56, 191-199.

Muthukumar, G., Nickerson, A. W. \& Nickerson, K. W. (1987). Calmodulin levels in yeasts and filamentous fungi. FEMS Microbiology Letters 41, 253-255.

O'Farrell, P. Z., Goodman, H. M. \& O'Farrell, P. H. (1977). High resolution two dimensional electrophoresis of basic as well as acidic proteins. Cell 12, 1133-1142.

PITT, D. (1970). Changes in hydrolase activity of Solanum tuber tissues during infection by Phytophthora erythroseptica. Transactions of the British Mycological Society 55, 257-266.

PItT, D. \& Kalle, A. (1990). Transduction of the calcium signal with special reference to $\mathrm{Ca}^{2+}$-induced conidiation in Penicillium notatum. In Biochemistry of Cell Walls and Membranes in Fungi, pp. 283-298. Edited by P. J. Kuhn, A. P. J. Trinci, M. J. Jung, M. W. Goosey \& L. G. Copping. Berlin: Springer-Verlag.

PitT, D. \& MosLey, M. J. (1985a). Enzymes of gluconate metabolism and glycolysis in Penicillium notatum. Antonie van Leeuwenhoek 51, 353-364.

Pitt, D. \& Mosley, M. J. (1985b). Pathways of glucose catabolism and the origin and metabolism of pyruvate during calcium-induced conidiation of Penicillium notatum. Antonie van Leeuwenhoek 51, 365-385.

PITT, D. \& Mosley, M. J. (1986). Oxidation of carbon sources via the tricarboxylic acid cycle during calcium-induced conidiation of Penicillium notatum. Antonie van Leeuwenhoek 52, 467-482.

PItT, D. \& Poole, P. C. (1981). Calcium-induced conidiation in Penicillium notatum in submerged culture. Transactions of the British Mycological Society 76, 219-230.
PitT, D. \& STEWART, P. (1981). Isolation and characterization of components of the lytic compartment of several plant tissues including separations with a zonal rotor. Annals of Botany $\mathbf{4 8}$, 665-692.

Pitt, D., Barnes, J. C. \& Ugalde, U. O. (1988). Differential uptake of calcium by strains of Penicillium notatum and relationships to calcium-induced conidiation. Transactions of the British Mycological Society 91, 489-499.

PrentKi, M., Janic, D. \& Wolmeim, C. B. (1983). The regulation of extra-mitochondrial steady state free $\mathrm{Ca}^{2+}$ concentration by rat insulinoma mitochondria. Journal of Biological Chemistry $\mathbf{2 5 8}$, $7597-7602$

Rink, T. J. \& Pozzan, T. (1985). Using quin-2 in cell suspensions. Cell Calcium 6, 133-144.

Robson, G. D., Trinci, A. P. J., Wiebe, M. G. \& Best, L. C. (1991). Phosphatidylinositol 4,5-biphosphate $\left(\mathrm{PIP}_{2}\right)$ is present in Fusarium graminearum. Mycological Research 95, 1082-1084.

Roncal, T., Ugalde, U. O., Barnes, J. C. \& Pitt, D. (1991). Production of protoplasts of Penicillium cyclopium with improved viability and functional properties. Journal of General Microbiology 137, 1647-1651.

Roos, W. \& LÜCKNER, M. (1984). Relationships between proton extrusion and fluxes of ammonium ions and organic acids in Penicillium cyclopium. Journal of General Microbiology 130, $1007-1014$.

SLAVIK, J. (1982). Intracellular $\mathrm{pH}$ of yeast cells measured with fluorescent probes. FEBS Letters 140, 22-26.

St Leger, R. J., Roberts, D. W. \& Staples, R. C. (1989). Calcium and calmodulin-mediated protein synthesis and protein phosphorylation during germination, growth and protein production by Metarhizium anisopliae. Journal of General Microbiology 135, 2141-2154.

Streb, H., Irvine, R. F., Berridge, M. J. \& Schulz, I. (1983). Release of $\mathrm{Ca}^{2+}$ from a non-mitochondrial intracellular store in pancreatic acinar cells by inositol-1,4,5-trisphosphate. Nature, London $\mathbf{3 0 6}$, $67-69$.

Tsien, R. Y., Pozzan, T. \& Rink, T. J. (1982). Calcium homeostasis in intact lymphocytes: cytoplasmic free calcium monitored with a new, intracellularly trapped fluorescent indicator. Journal of Cell Biology 94, 325-334.

UGaLdE, U. O. (1991). Preparation of highly purified plasma membrane vesicles of controlled orientation from Penicillium cyclopium. Mycological Research 95, 1303-1307.

Ugalde, U. O. \& Pitt, D. (1983). Morphology and calcium-induced conidiation of Penicillium cyclopium in submerged culture. Transactions of the British Mycological Society 80, 319-325.

Ugalde, U. O. \& PitT, D. (1984). Subcellular sites of calcium accumulation and relationships with conidiation in Penicillium cyclopium. Transactions of the British Mycological Society 83, 547-555.

Ugalde, U. O. \& PitT, D. (1986). Calcium uptake kinetics in relation to submerged cultures of Penicillium cyclopium. Transactions of the British Mycological Society 87, 199-203.

Ugalde, U. O., ViRTo, M. D. \& Pitt, D. (1990). Calcium binding and induction of conidiation in protoplasts of Penicillium cyclopium. Antonie van Leeuwenhoek 57, 43-49.

Ugalde, U. O., Henandez, A., Galindo, I., Pitt, D., Barnes, J. C. \& W AKLEY, G. (1992). Preparation of right-side-out plasma membrane vesicles from Penicillium cyclopium: critical assessment of markers. Journal of General Microbiology 138, 2205-2212.

WeEte, J. D. (1974). Fungal Lipid Biochemistry. London: Plenum. 